\title{
NIPHARGUS SARII SP. N., A NEW SUBTERRANEAN NIPHARGID (CRUSTACEA: AMPHIPODA) FROM IRAN BASED ON MOLECULAR AND MORPHOLOGICAL CHARACTERS
}

\author{
Somayeh Esmaeili-Rineh, Ali Mohammad-Niakan and Vahid Akmali ${ }^{*}$ \\ Department of Biology, Faculty of Science, Razi University, Kermanshah, Iran \\ *E-mail:v_akmali@razi.ac.ir
}

Niphargus sarii sp. n. was collected from Jo-Khanem Spring in Ilam Province. This species hypothesis is based on the analysis of morphological characters and $28 \mathrm{~S}$ ribosomal DNA sequences. In this paper, we describe the morphological traits of this new species. Then, its taxonomic status within the genus is discussed in comparison to the 15 known Iranian species. Results revealed that $N$. sarii sp. $\mathrm{n}$. is phylogenetically close to $N$. sohrevardensis. This species is easily distinguished from other Iranian species by some characters, in particular the equal length of rami in uropod I, lack of lateral robust setae on telson and the situation of dactylus to posterior margin of propodus in gnathopod II.

Keywords: Niphargus, Jo-Khanem Spring, Zagros Mountains, 28SrDNA, morphological characters, Iran.

\section{INTRODUCTION}

The Zagros Mountains range has a total length of $1600 \mathrm{~km}$ from northeast Iraq to the Strait of Hormuz and its elevation gradually declines toward the Persian Gulf (RAeisi 2004). This region is composed mainly of the karstic carbonate formations, and its karstic aquifers are among the most important karst reservoirs in the western part of Iran (RAeisi \& Stevanovic 2010). Due to the wide geographical range and geological conditions coupled with the climatologically diverse environments, the Zagros Mountains range provides a great diversity of species in aquatic and terrestrial habitat types (SMITH 1953, Sargeran et al. 2008, Akmali et al. 2011, Esmaeili-Rineh et al. 2016a, EsmaeiliRineh et al. 2016b, Аfroosheh et al. 2016, Fathipour et al. 2016, Shahabi et al. 2017, Mamaghani-Shishvan et al. 2017), and it is considered as a centre for the origin of numerous species (COAD \& VILENKIN 2004).

The survey of species diversity in freshwater habitats indicates that large numbers of animal species are endemic in this part including the members of the genus Niphargus Schiödte, 1849 (Niphargidae, Amphipoda). These blind and depigmented animals normally live in subterranean freshwater ecosystems, and only a few niphargids of them occur in the surface waters (SKET 1981). They are distributed across most of Europe, and few species are known from the Middle East (FIšER 2012). Many of the 330 described species are 
known only from their type localities. According to Christman et al. (2005), endemism or the restriction of taxa to a particular geographic area is very high in subterranean fauna due to the poor migratory capabilities.

So far, 16 species were described from Elburz (2 species) and Zagros Mountains ranges (14 species) in Iran. The described species have been found in the karstic areas including three from caves and the rest of the springs, but there are also species that are found in both cave and spring waters (e.g. $N$. hosseiniei). The most of them are endemic with narrow range. In contrast, some species such as $N$. khwarizmi have wide range, the distance between the two populations of this species is about $570 \mathrm{~km}$ (EsmaEILI-RINEH et al. 2015a). In this paper, we present results of a recent survey on niphargid fauna from Ilam Province and describe a new endemic species of this genus.

\section{MATERIAL AND METHODS}

\section{Study area}

The specimens were collected using a small hand net in Jo-Khanem Spring $\left(33^{\circ} 19^{\prime} \mathrm{N}\right.$, $46^{\circ} 40^{\prime} \mathrm{E}$ ) close to Chardavol City in Ilam Province (Fig. 1).The Ilam Province is located in the western and southwestern regions of the Iranian Plateau between $31^{\circ} 58^{\prime}$ to $34^{\circ} 15^{\prime} \mathrm{N}$ and $45^{\circ} 24^{\prime}$ to $48^{\circ} 10^{\prime}$ E. Altitude ranges from $50 \mathrm{~m}$ a.s.l. in the south to $3062 \mathrm{~m}$ in the Kabir-

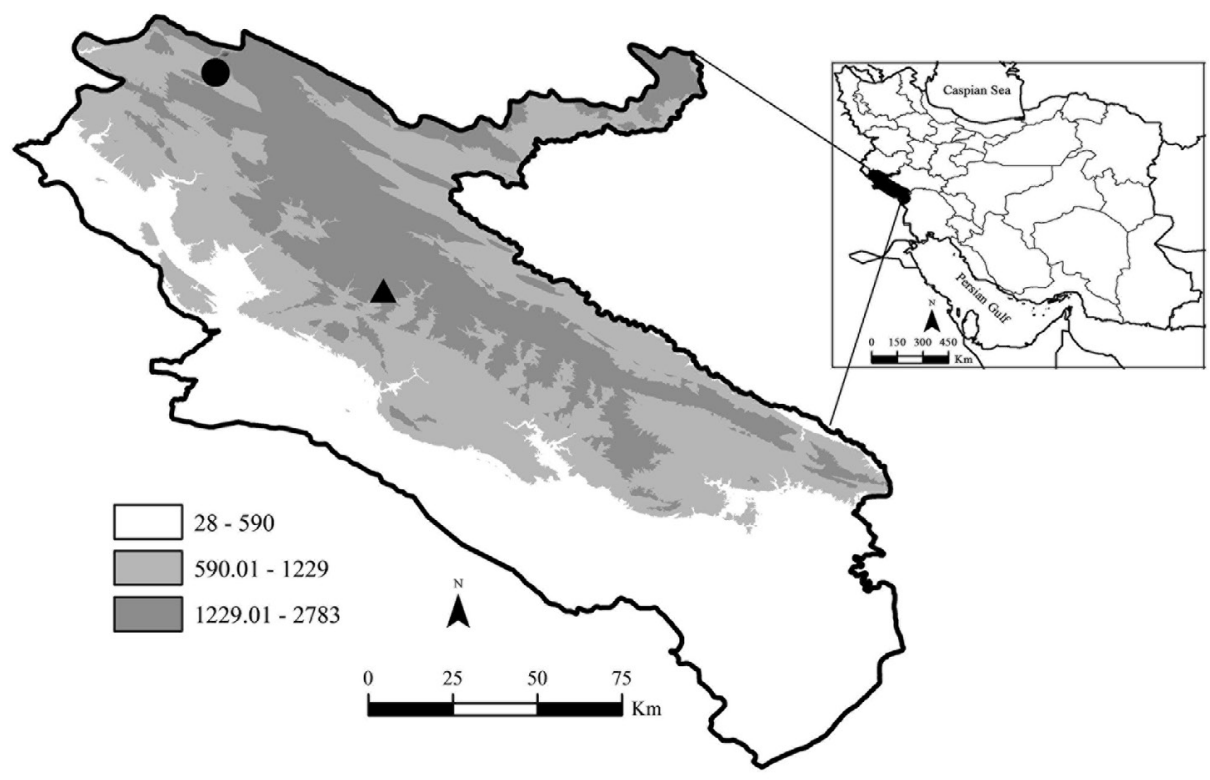

Fig. 1. Marks on the map are representing localities of $(\bullet)$ N. ilamensis and the newly described species $(\boldsymbol{\Delta})$ N. sarii sp. n. 
Kouh Mountain (to the east of the province). So far, N. ilamensis was found from this region in north part of Ilam Province.

\section{Morphological and morphometric studies}

Characters of individual specimens were measured according to Fišse et al. (2009) and then mounted on slides in a Euparal medium. Digital photos were taken with an Olympus LABOMED iVu 7000 camera fitted on an LABOMED Lx500 stereomicroscope. Measurements and counts were made using the computer program ProgRes CapturePro 2.7. The specimens used for the present study are deposited in the Zoological Collection of Razi University (ZCRU).

\section{Phylogenetic analyses and molecular divergence}

We extracted total genomic DNA from a part of the animal using Tissue Kits (Gen$\mathrm{NetBio}^{\mathrm{TM}}$ ), following the manufacturer's instructions (Seoul, South Korea). A $810 \mathrm{bp}$ of the first fragment of $28 \mathrm{~S}$ ribosomal DNA were amplified and sequencing using the forward primer from VerovNiK et al. (2005) and the reverse primer from ZАKšEK et al. (2007). Polymerase chain reactions (PCRs) in a final volume of $25 \mu \mathrm{l}$ contained optimized amounts of PCR water, $12.5 \mu \mathrm{l}$ of Master Mix kit (Sinaclon, Iran), $0.2 \mu \mathrm{l}$ of each primer $(10 \mu \mathrm{M})$, and 50-100 ng of genomic DNA template. PCR cycling settings were as follows: initial denaturation of $94^{\circ} \mathrm{C}$ for 7 minutes, 35 subsequent cycles of $94^{\circ} \mathrm{C}$ for 45 seconds, $55^{\circ} \mathrm{C}$ for 30 seconds and $72^{\circ} \mathrm{C}$ for 1 minute, and a final extension of $72^{\circ} \mathrm{C}$ for 7 minutes. Purification of PCR products and sequencing were commercially performed by Macrogen Inc. (Korea).

In order to figure out the phylogenetic position of the new species, we analysed the acquired sequences within the data set of Esmaeili-RINeH et al. (2015a, 2017a) (Table 1, all samples included in analyses). All the sequences were edited and aligned using Clustal W (Tномтsоn et al. 1994), as implemented in the Bioedit program sequence alignment editor (Hall 1999) using the default settings.

Phylogenetic reconstruction was performed using the Bayesian inferences in MRBAYES, version 3.1.2 (Ronquist \& HuELSENBECK 2003) and Maximum likelihood (ML) with PHYML, version 3.0 software (GuIDON \& GAscuel 2003). The appropriate model for BI and ML analysis was selected with jModelTest, version 0.1.1 (PosADA 2008) using Akaike Information Criterion. The best fit model identified by AIC for phylogenetic reconstruction was GTR+I+G. Bayesian analyses were run for 5 million generations, with four chains, and trees sampled every 1000 generations. The first 1250 sampled trees were discarded as burn-in, and subsequent tree likelihoods were checked for convergence in Tracer 1.5.0 (RAMBAUT \& DRUMmond et al. 2012). A fifty percent majority rule consensus tree was computed using the remaining trees and visualized by FigTree v1.4.0 software. In ML analysis a starting tree was obtained by BIONJ and nodal support was estimated from 1000 bootstrap replicates.

To assess interspecific divergence between the Iranian species of Niphargus, we calculated the genetic distances corrected with Kimura two-parameter (K2P) model (KImURA 1980) as implemented in MEGA ver. 5 (TAMURA et al. 2011) and Patristic distances from a maximum likelihood (ML) tree as described in Fourment and Gibbs (2006) in the PATRISTIC v1.0 program. Patristic distances have been broadly used in Niphargus taxonomy so far; as such warrant compatibility of the results across different studies (LÉFEBURE et al. 2006, Meleg et al. 2013). 
Table 1. List of taxa used in the analyses and their geographic origin. Newly obtained sequences are written in bold.

\begin{tabular}{|c|c|c|}
\hline Taxon & Acc. no. $28 \mathrm{~S}$ & Origin of samples \\
\hline N. alisadri Esmaeili-Rineh et Sari, 2013 & KF581049 & Alisadr Cave, Hamedan Prov., Iran \\
\hline N. aquilex Schiödte, 1855 & EF617264 & $\begin{array}{l}\text { North German Plain, Weser, Hessisch Olden- } \\
\text { dorf, Germany }\end{array}$ \\
\hline N. arbiter G. Karaman, 1984 & EF617287 & Tounjčica Cave, Ogulin, Croatia \\
\hline N. carniolicus Sket, 1960 & EF617252 & Lukenjska jama, Prečna, Slovenia \\
\hline N. costozzae Schellenberg, 1935 & EU693294 & Grotta della Guerra Cave, Berici Mt., Italy \\
\hline N. dalmatinus Shäfferna, 1922 & EF617296 & Vrana Spring, Zadar, Herzegovina. \\
\hline N. daniali Esmaeili-Rineh et Sari, 2013 & KF581033 & Danial Cave, Mazandaran Prov., Iran \\
\hline N. dimorphus Birstein, 1961 & KF719273 & $\begin{array}{l}\text { Vodnjak v vrtnariji, Zarečnoe, ESE, Simfer- } \\
\text { opol', Krym, Ukraine }\end{array}$ \\
\hline N. dolichopus Fišer et al., 2006 & EU693297 & $\begin{array}{l}\text { Suvaja pećina, Lušci polje, Sanski most, Bosnia } \\
\text { and Herzegovina }\end{array}$ \\
\hline N. fontanus Bate, 1859 & EF617265 & Little stour, Kent, VB, Belgium \\
\hline N. gabrovceci S. Karaman, 1952 & EU693299 & spring near village Gabrovčec, Krka, Slovenia \\
\hline N. zagrebensis cf. gadina & EF617295 & $\begin{array}{l}\text { Žopenca-Gadina cave, Kočevje, Črnomelj, } \\
\text { Slovenia }\end{array}$ \\
\hline N. grandii Ruffo, 1937 & EU693300 & streamTorre, $\mathrm{N}$ of Ruda, Italy \\
\hline N. hadzii Rejic, 1956 & EU693301 & $\begin{array}{l}\text { »Pod orehom« spring, Verd, Vrhnika, Lu- } \\
\text { bljana, Slovenia }\end{array}$ \\
\hline Niphargus hvarensis S. Karaman, 1952 & EU693303 & spring at the church, Slano, Coratia \\
\hline N. illidzensis Schäferna, 1922 & EU693304 & $\begin{array}{l}\text { spring of river Bosna, Ilidža, Sarajevo, Bosnia } \\
\text { and Herzegovina }\end{array}$ \\
\hline N. karamani Schellenberg, 1935 & EU693305 & well, Fram 119, Maribor, Slovenia \\
\hline N. khayyami Hekmatara et al., 2013 & JX535353 & $\begin{array}{l}\text { Ghori- Ghale Cave, Ravansar-Paveh road, } \\
\text { Kermanshah Prov., Iran }\end{array}$ \\
\hline N. khwarizmi Hekmatara et al., 2013 & KF581056 & Kahriz Spring, Khoranagh, E Azarbayejan, Iran \\
\hline N. krameri Schellenberg, 1935 & EF617274 & subsidiary stream of river Fojba, Pazin, Croatia \\
\hline N. lessiniensis Stoch, 1998 & EF617300 & $\begin{array}{l}\text { Grotta dell Aqua, Ponte de Veja, Monti } \\
\text { Lessini,Verona, Italy }\end{array}$ \\
\hline N. longicaudatus cf. cres & EF617240 & $\begin{array}{l}\text { Retec spring, Lubenice, island of Cres, Bosnia } \\
\text { and Herzegovina }\end{array}$ \\
\hline N. longicaudatus Costa, 1951 & EF617241 & $\begin{array}{l}\text { spring at the road, between Monte Faito and } \\
\text { Vico Equense, Napoli, Italy }\end{array}$ \\
\hline N.novomestanus S. Karaman, 1952 & EU693314 & $\begin{array}{l}\text { Tominčev studenec spring, Dvor, Žužemberk, } \\
\text { Slovenia }\end{array}$ \\
\hline N. orcinus Joseph, 1869 & EU693315 & Križna jama, Lož, Slovenia \\
\hline N. pasquinii Vigna-Taglianti, 1966 & EF617244 & Sorgenti di S spring. Vittorino, Rieti, Lazio, Italy \\
\hline N. polymorphus Fišer et al., 2006 & EF617282 & $\begin{array}{l}\text { Obodska pećina cave, Rijeka Crnojevića, } \\
\text { Montenegro }\end{array}$ \\
\hline
\end{tabular}


Table 1 (continued)

\begin{tabular}{|c|c|c|}
\hline Taxon & Acc. no. $28 S$ & Origin of samples \\
\hline N. puteanus Koch, 1836 & EF617302 & $\begin{array}{l}\text { spring at the guesthouse Zur Walba, Regens- } \\
\text { burg, Germany }\end{array}$ \\
\hline N. rejici Sket, 1958 & EF617283 & $\begin{array}{l}\text { spring at lake Podpeško jezero, Ljubljana, } \\
\text { Slovenia }\end{array}$ \\
\hline N. sanctinaumi S. Karaman, 1943 & EU693320 & Naum spring, Ohrid, Macedonia \\
\hline N. schellenbergi S. Karaman, 1932 & EU693321 & Hessen, Kammerbacher Hohle, Germany \\
\hline N. spinulifemur S. Karaman, 1954 & EU693323 & brook NE from village Hrastovlje, Slovenia \\
\hline N. spoeckeri Schellenberg, 1933 & EU693324 & Pivka jama, Postojna, Slovenia \\
\hline N. stygius Shiödte, 1847 & EU693325 & Pred jama, Postojna, Slovenia \\
\hline N. subtypicus Sket, 1960 & EU693326 & Lukenjska jama, Prečna, Novo mesto, Slovenia \\
\hline N. timavi S. Karaman, 1954 & EU693327 & Grotte di Trebiciano (Labodnica), Trst, Italy \\
\hline N. trullipes Sket, 1958 & EF617281 & Vjetrenica cave, Zavala, Bosnia and Herzegovina \\
\hline N. vadimi Birstein, 1961 & KF719275 & Skel'skaja peščera, Rodnikovo, Krym, Ukraine \\
\hline N. valvasori S. Karaman, 1952 & EU693328 & Križna jama, Lož, Slovenia \\
\hline N. vinodolensis Fišer et al., 2006 & EF61729 & $\begin{array}{l}\text { Stream below the bridge, Ceroviči, Vinodol, } \\
\text { Bosnia and Herzegovina }\end{array}$ \\
\hline N. vjeternicensis S. Karaman, 1932 & EU693329 & $\begin{array}{l}\text { Vjetrenica Cave, Zavala, Bosnia and Herze- } \\
\text { govina }\end{array}$ \\
\hline N. hosseiniei Esmaeili-Rineh et al., 2017 & KF581054 & Brolan Spring, West Azarbayejan, Iran \\
\hline N. hosseiniei Esmaeili-Rineh et al., 2017 & KF581055 & Nojivaran Spring, Kermanshah Prov., Iran \\
\hline N. hosseiniei Esmaeili-Rineh et al., 2017 & $\begin{array}{l}\text { KF581036 } \\
\text { KF581047 }\end{array}$ & Tir-e-Bagh Spring, Fars Prov., Iran \\
\hline N. ilamensis Esmaeili-Rineh et al., 2017 & KF581039 & Sarab-e-Moord, Ilam Prov., Iran \\
\hline N. ilamensis Esmaeili-Rineh et al., 2017 & KF581038 & Sarab-e-Kanipahn, Ilam Prov., Iran \\
\hline $\begin{array}{l}\text { N. sohrevardensis Esmaeili-Rineh et } \\
\text { al., } 2017\end{array}$ & KF581035 & Sohrevard Spring, Zanjan Prov., Iran \\
\hline $\begin{array}{l}\text { N. bisitunicus Esmaeili-Rineh et al., } \\
2015\end{array}$ & KF581050 & Sarab-e-Bisitun, Kermanshah Prov., Iran \\
\hline N. khayyami Hekmatara et al., 2013 & KF581058 & Ghori- Ghale Cave, Kermanshah Prov., Iran \\
\hline N. darvishi Esmaeili-Rineh et al., 2015 & KF581043 & $\begin{array}{l}\text { Dimeh Spring, Chaharmahal- va- Bakhtiari } \\
\text { Prov., Iran }\end{array}$ \\
\hline N. sharifii Esmaeili-Rineh et al., 2015 & KF581048 & Sarab-e-Robat, Lorestan Prov., Iran \\
\hline N. khwarizmi Hekmatara et al., 2013 & $\begin{array}{l}\text { KF581057 } \\
\text { KF581051 }\end{array}$ & Sarab-e-Niaz, Lorestan Prov., Iran \\
\hline $\begin{array}{l}\text { N. sohrevardensis Esmaeili-Rineh et } \\
\text { al., } 2017\end{array}$ & KF581034 & Razbashi Spring, Lorestan Prov., Iran \\
\hline N. sharifii Esmaeili-Rineh et al., 2015 & KF581037 & $\begin{array}{l}\text { Gahroo Spring, Chaharmahal- va- Bakhtiari } \\
\text { Prov., Iran }\end{array}$ \\
\hline N. borisi Esmaeili-Rineh et al., 2015 & KF581044 & $\begin{array}{l}\text { Belqais Spring, Kohgiloyeh- va- Boyerahmad } \\
\text { Prov., Iran }\end{array}$ \\
\hline
\end{tabular}


Table 1 (continued)

\begin{tabular}{|c|c|c|}
\hline Taxon & Acc. no. $28 \mathrm{~S}$ & Origin of samples \\
\hline $\begin{array}{l}\text { N. kermanshahi Esmaeili-Rineh et } \\
\text { al., } 2016\end{array}$ & $\begin{array}{l}\text { KX232639 } \\
\text { KX232640 }\end{array}$ & $\begin{array}{l}\text { Kangarshah Spring close to Sahneh City, } \\
\text { Kermanshah Prov., Iran }\end{array}$ \\
\hline N. sariei this study & - & $\begin{array}{l}\text { Jo-Khanem Spring close to Chardavol City, } \\
\text { Ilam Prov., Iran }\end{array}$ \\
\hline N. hakani Esmaeili-Rineh et al., 2017 & $\begin{array}{l}\text { KY629001 } \\
\text { KY629002 }\end{array}$ & $\begin{array}{l}\text { Kheder-Goli spring, Razan city, Hamedan } \\
\text { Prov., Iran }\end{array}$ \\
\hline N. darvishi Esmaeili-Rineh et al., 2015 & $\begin{array}{l}\text { KF581042 } \\
\text { KF581071 }\end{array}$ & $\begin{array}{l}\text { Gholam-Abad Spring, Chaharmahal- va- } \\
\text { Bakhtiari Prov., Iran }\end{array}$ \\
\hline Niphargus sp. & $\begin{array}{l}\text { KF581059 } \\
\text { KF581081 }\end{array}$ & $\begin{array}{l}\text { Magharit cave, L-Mascat, Ras Chekka, Bat- } \\
\text { roun, Lebanon }\end{array}$ \\
\hline Gammarus fossarum Koch, 1935 & $\begin{array}{l}\text { EF617235 } \\
\text { KF719241 }\end{array}$ & $\begin{array}{l}\text { stream near Dept. Biology, Ljubljana city, } \\
\text { Slovenia }\end{array}$ \\
\hline $\begin{array}{l}\text { Pontogammarus crassus G. O. Sars, } \\
1894\end{array}$ & $\begin{array}{l}\text { KF719277 } \\
\text { KF719242 }\end{array}$ & L. Razim, Jurilovka, Babadag, Italy \\
\hline Synurella ambulans Müller, 1846 & $\begin{array}{l}\text { EF617236 } \\
\text { KF719240 }\end{array}$ & Biološko središče, Ljubljana, Slovenia \\
\hline
\end{tabular}

\section{RESULTS}

Niphargus sarii sp. n.

(Figs 2-5)

URN:1sid:zoobank.org:pub:F0FCBA2D-3B44-46C0-9A71-2D529B13B26F

Holotype: male specimen $(11.5 \mathrm{~mm})$ from Jo-Khanem Spring, Chardavol City, Ilam Province, Iran; $\left(33^{\circ} 19^{\prime} \mathrm{N}, 46^{\circ} 40^{\prime} \mathrm{E}\right)$. Specimens were collected by A.M. Niakan in May 2014. Holotype with two paratypes is stored under catalogue number ZCRU Amph.1001 in the Zoological Collection of Razi University, Iran (ZCRU).

Diagnosis - The rami in uropod I have equal length. The urosomites I to II bear dorso-laterally one and two robust setae accompanied with one simple seta, respectively. The propods of gnathopods I to II are broader than long. The dactylus of gnathopod II is not reaching to the posterior margin of propodus.

Description of holotype - Total length of specimen $11.5 \mathrm{~mm}$. Body strong and stout. Head length $13 \%$ of body length (Fig. 2). Antennae I (Fig. 2) 0.47 of body length. Peduncular articles 1-3 progressively shorter; peduncular articles 2: 3 ratio 2: 1; main flagellum with 37 articles (most of which with short setae); accessory flagellum biarticulated and reaching $1 / 2$ of article 4 of main flagellum, flagellar articles 1 and 2 with two and three simple setae, respectively (Fig. 2). Length ratio of antenna I : II as $1: 0.45$. Peduncular article 4 as long as article 5, with nine and eight groups of simple setae, respectively; flagellum with 13 articles. Length of flagellum: length of peduncle article $4+5$ as $0.56: 1$ (Fig. 2).

Labium (Fig. 3) with inner lobes and setae on tip of lobes. Inner plate of maxilla I with four long simple setae; outer plate with seven long robust setae with 1-0-2-0-2-5-0 apical 
lateral projections; palp biarticulated, longer than outer lobe, with three long distal simple setae (Fig. 2). Both plates of maxilla II with numerous distal simple setae, with four lateral simple setae (Fig. 3). Incisor in left mandible with five teeth, lacinia mobilis with four teeth; six setae with lateral projections between lacinia and triturative molar (Fig. 2). Incisor in right mandible with four teeth, lacinia mobilis pluritooth; seven setae with lateral projec-

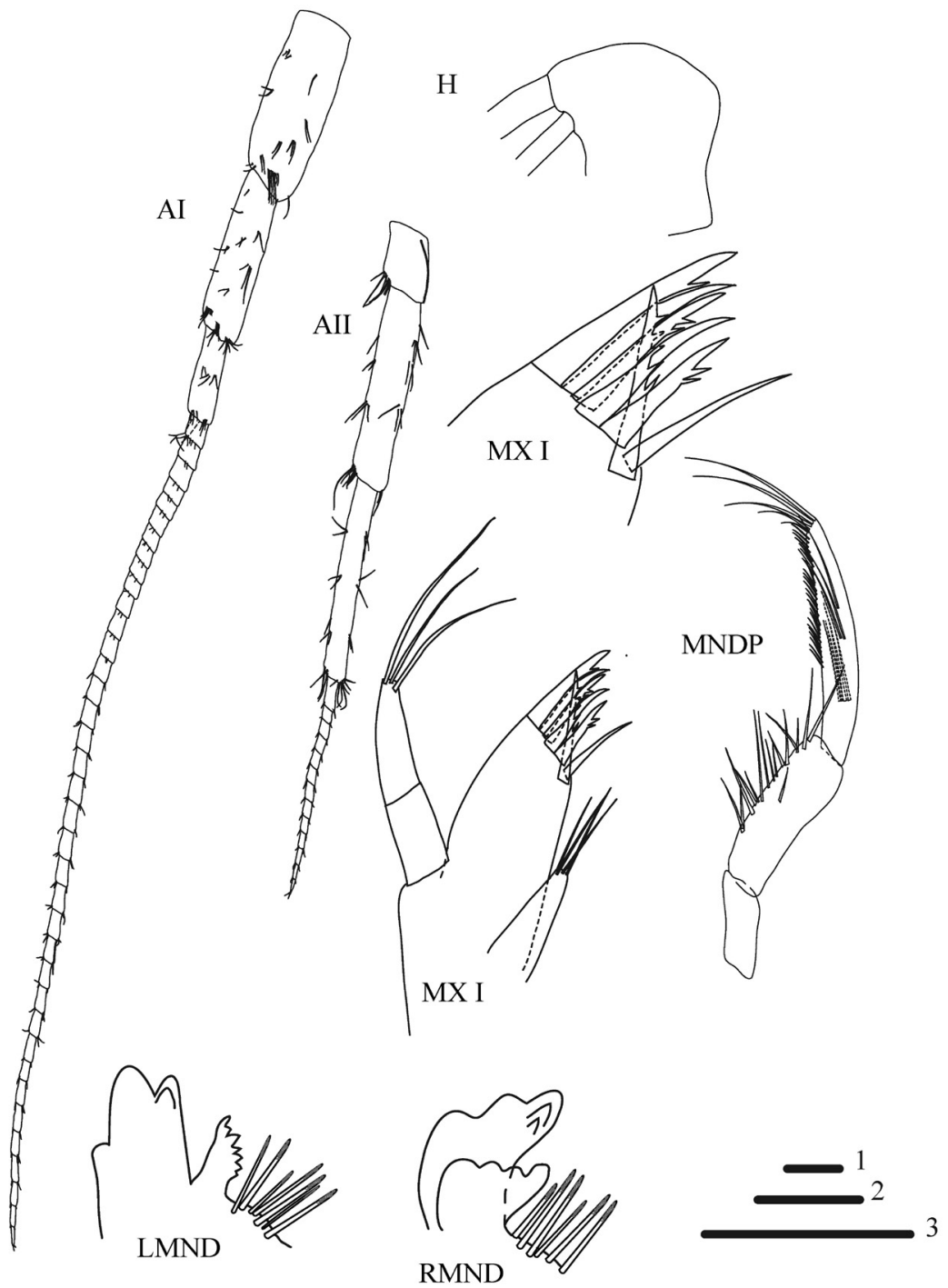

Fig. 2. Niphargus sarii sp. n., male $11.5 \mathrm{~mm}$ (holotype, ZCRU Amph.1001). AI = antenna I, $\mathrm{AII}=$ antenna II, $\mathrm{H}=$ head, $\mathrm{MX} \mathrm{I}=$ maxilla $\mathrm{I}$ and outer plate of maxilla $\mathrm{I}, \mathrm{MNDP}=$ mandibular palp, $\mathrm{LMND}=$ left mandible, RMND = right mandible. Scale bars: $1=0.25 \mathrm{~mm}$ (LMND, RMND), 2 = 0.5 mm (H, MX I, MNDP), 3 = 1mm (AI-AII) 
tions between lacinia and triturative molar (Fig. 2). Mandibular palp articles ratios $1: 2$ : 3 as $1: 1.58: 2.41$. The proximal article has no setae, the second article with 16 setae along inner margin and the third article with one group of four A-setae, two groups of B-setae, no C-setae, 25 D-setae and four E-setae (Fig. 2).

Maxilliped with short inner plate on which are three distal robust setae intermixed with six distal simple setae; outer plate exceeding the proximal half of the posterior margin of palp article 2, with 12 robust setae along inner margin and four simple setae distally. Palp article 3 of maxilliped with one proximal, inner and outer group of long simple setae at outer margin; terminal article of palp with one simple seta at outer margin, nail shorter than pedestal (Fig. 3).

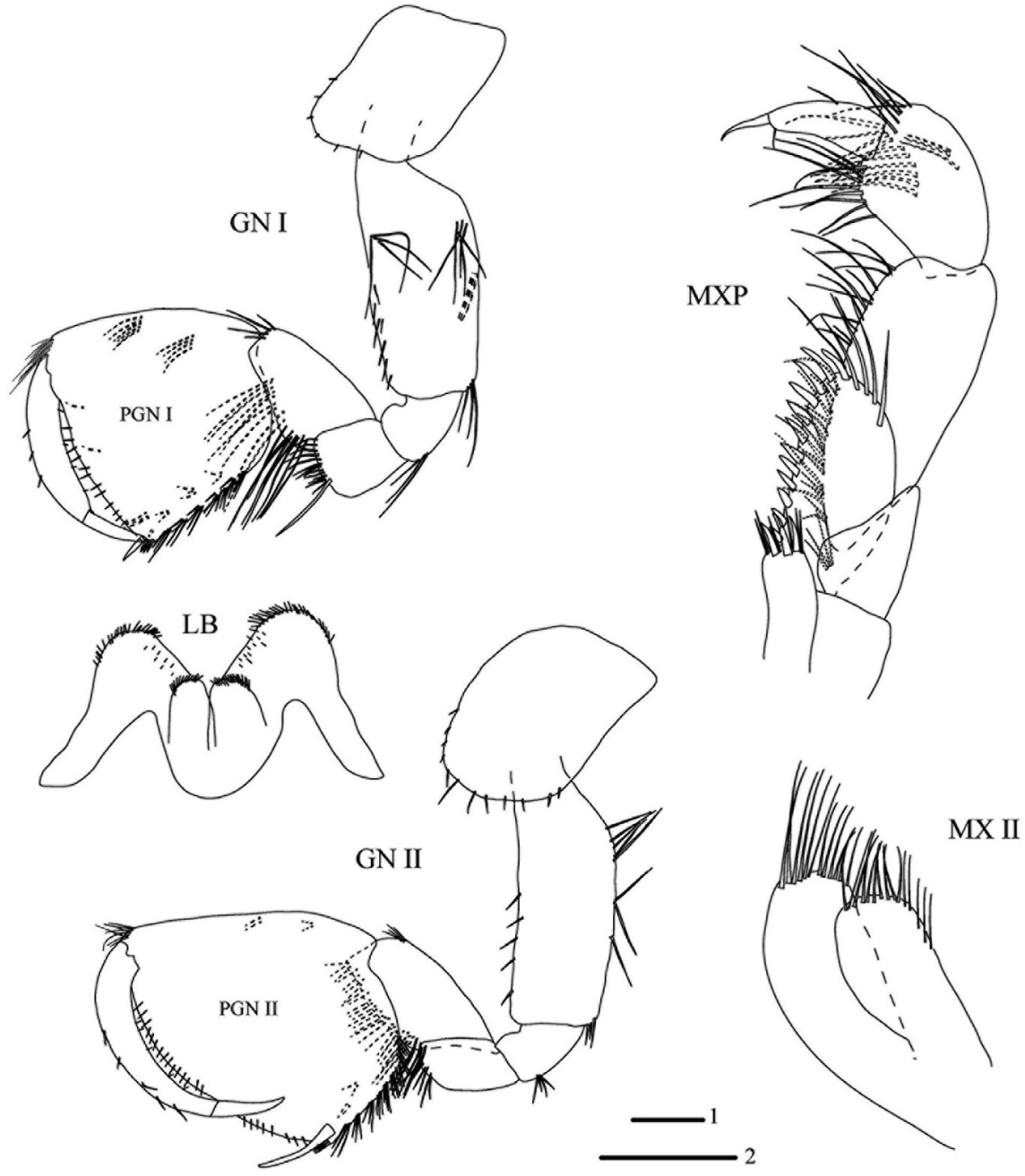

Fig. 3. Niphargus sarii sp. n., male, holotype, $11.5 \mathrm{~mm}$. Legend: GN I = gnathopod I, GN II = gnathopod II, LB = labium, MXP = maxilliped, MX II = maxilla II. Scale bars: $1=0.5 \mathrm{~mm}(\mathrm{LB}$, MXP, MX II), 2 = 1 mm (GN I-II) 
Coxa of gnathopod I shorter than coxa of gnathopod II. Coxa I rectangular, longer than broad, ventral to anterior margin each with three simple setae. Basis with setae along anterior and posterior margins; ischium and merus with posterior group of setae. Carpus with one group of four setae anterodistally, a bulge with long simple setae; carpus 0.54 of basis length and 0.71 of propodus length. Propodus slightly broader than long; anterior margin with nine setae in two groups in addition to anterio-distal group of nine simple setae. Palm slightly convex, with one strong long palmar robust seta, one short supporting robust seta on inner surface, with three robust setae with lateral projections on outer surface; two simple setae under supporting robust seta in palmar corner. Dactylus reaching posterior margin of propodus, outer and inner margins with a row of three and five simple setae, respectively; nail short, 0.23 of total dactylus length (Fig. 3).

Coxa of gnathopod II rectangular, with 12 setae along anterio-ventro-posterior margins. Basis with setae along anterior and posterior margins; posterior margins of ischium and merus with one posterior group of setae each. Carpus 0.64 of basis length and 0.69 propodus length. Carpus with one group of four setae antero-distally. Propodus in gnathopod II larger than gnathopod I, trapezoid shape and broader than long; anterior margin

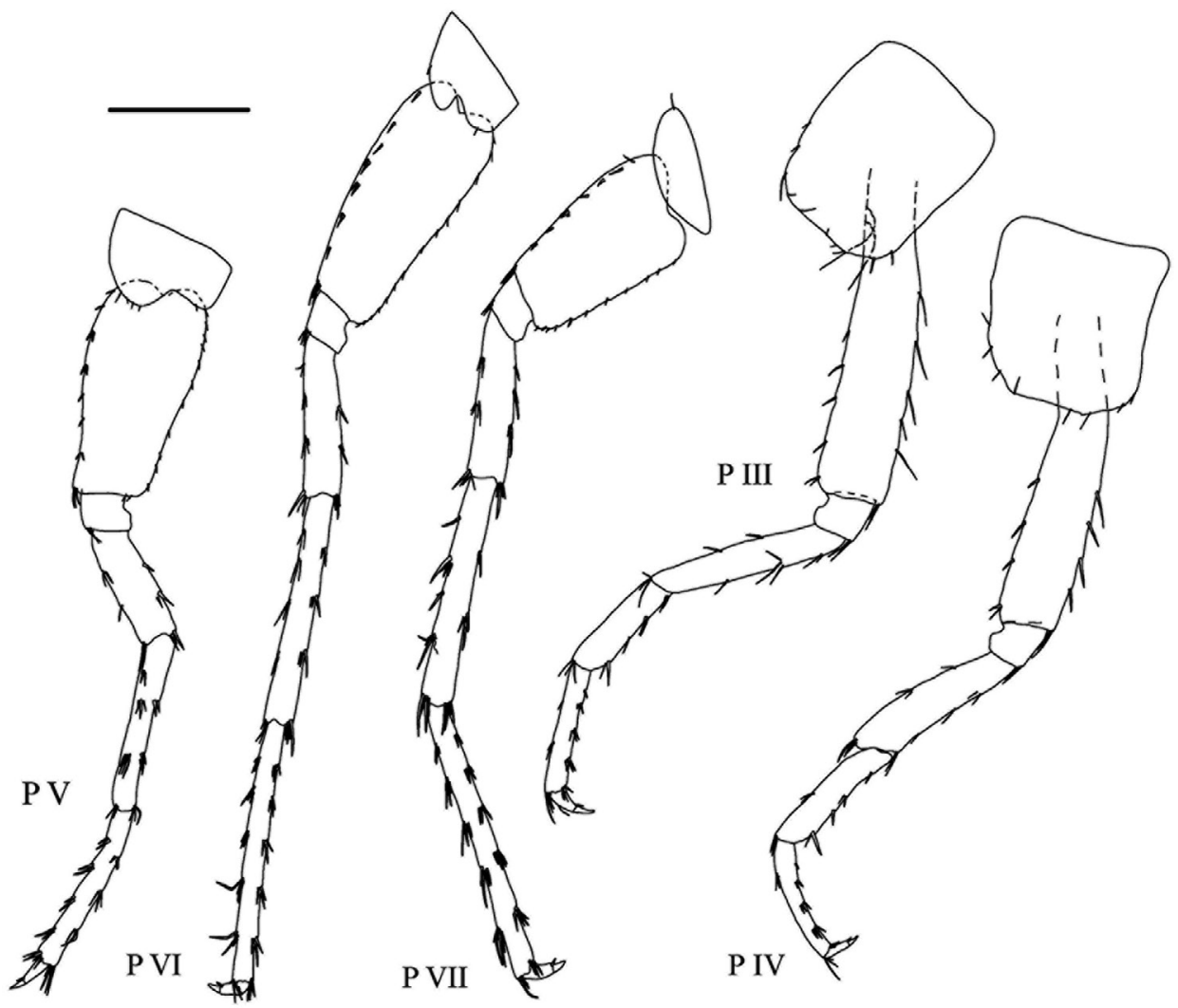

Fig. 4. Niphargus sarii sp. $\mathrm{n}$., male, holotype, $11.5 \mathrm{~mm}$. Legend: $\mathrm{P} \mathrm{III}=$ pereopod III, $\mathrm{P} \mathrm{IV}=$ pereopod IV, P V = pereopod V, P VI = pereopod VI, P VII = pereopod VII. Scale bar: $1 \mathrm{~mm}$ (P III-P VII) 
with totally four setae in two groups in addition to antero-distal group of eight simple setae. Palm nearly convex, with one strong palmar robust seta, one supporting robust seta without lateral projections on inner surface, with two robust setae with lateral projections

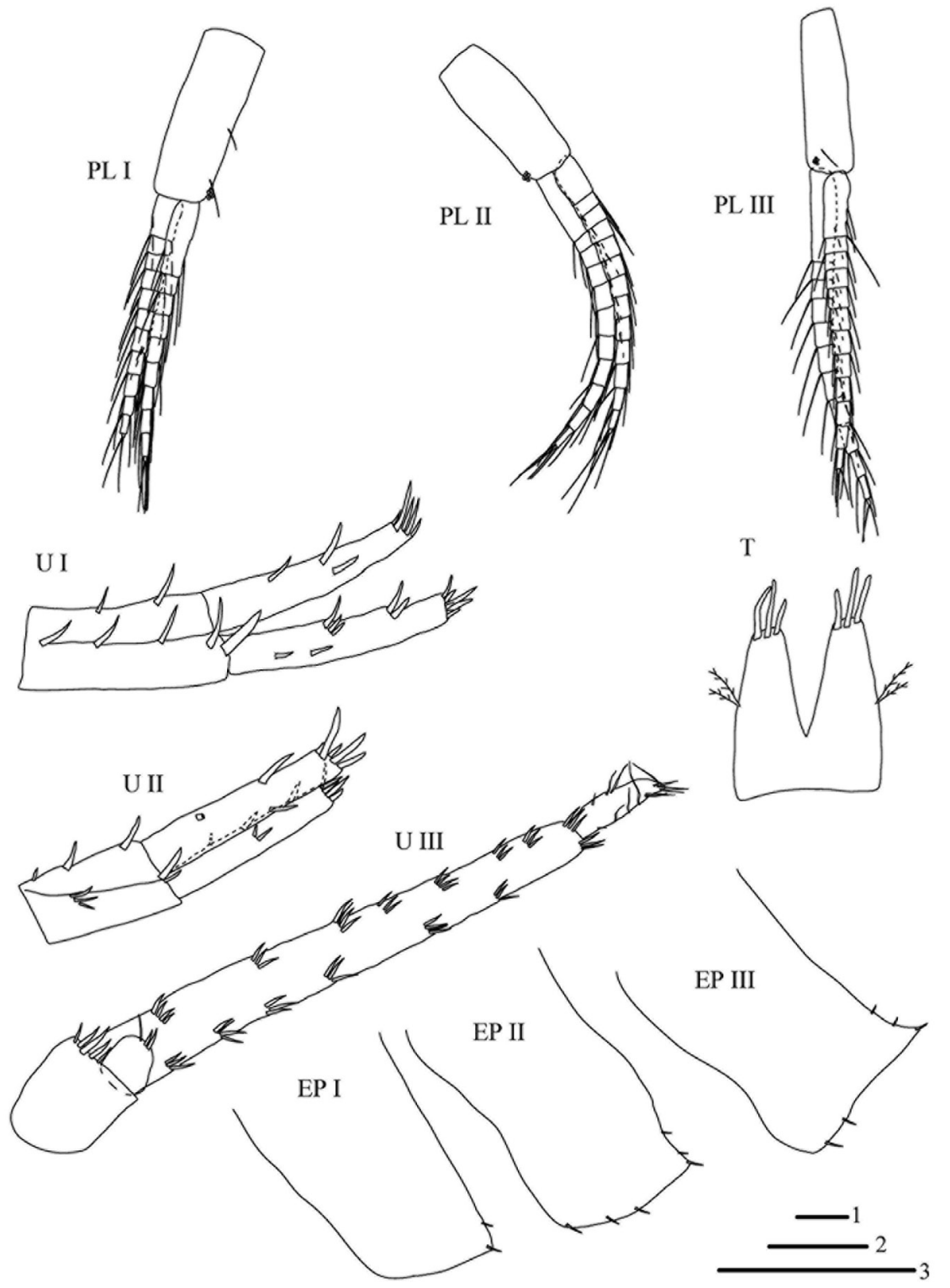

Fig. 5. Niphargus sarii sp. n., male, holotype, $11.5 \mathrm{~mm}$. Legend: $\mathrm{PL}$ I = pleopod I, PL II = poleopod II, PL III = pleopod III, U I = uropod I, U II = uropod II, U III = uropod III, EP I-III = epimeral plates I-III, T = telson. Scale bars: $1=0.5 \mathrm{~mm}$ (EP I-III, T), $2=1 \mathrm{~mm}$ (PL I-III, U I-II), $3=2 \mathrm{~mm}$ (U III) 
on outer surface; two setae under supporting robust seta in palmar corner. Dactylus is not reaching posterior margin of propodus, outer and inner margins of dactylus each with five simple setae. Nail length 0.25 of total dactylus length (Fig. 3).

Coxa III rectangular, length to width ratio as $1.24: 1$; antero-ventro-posterior margin with 10 simple setae. Coxa IV rectangular, length to width ratio as $1.36: 1$, antero-ventroposterior margin with eight simple setae, posterior concavity shallow and approximately 0.1 of coxa width (Fig. 4). Coxa V with anterior lobe, with four and one simple setae on anterior and posterior lobes, respectively. Coxa VI with anterior lobe, with one simple seta on anterior and posterior lobes each. Coxa VII with one simple seta (Fig. 4).

Pereonites I-VI without setae. Pereonite VII with one simple seta along dorsal surface. Pereopod III : IV lengths ratio as 1.08 : 1 (Fig. 4). Dactylus IV short, length of dactylus 0.36 of propodus, nail shorter than pedestal (Fig. 4). Pereopods V: VI: VII length ratios as 1 : $1.26: 1.17$, respectively. Pereopod VII 0.52 of body length. Pereopod bases V-VI each with eight groups of robust setae and pereopod basis VII with 12 simple setae along anterior margin, respectively. Pereopod bases V-VI with 13 and 14 simple setae and pereopod basis VII with eight groups of robust setae along posterior margin, respectively (Fig. 4). Posteroventral lobe of ischium in pereopods V-VII weakly developed. Ischium, merus and carpus in pereopods V-VII with several groups of robust and simple setae along anterior and posterior margins; propodus of pereopod VII longer than these in V-VI, dactyli of pereopods V-VII with one robust and one short simple seta at the base of nail on inner margin, nail length of pereopod VII 0.29 of total dactylus length (Fig. 4).

Epimeral plates I-III (Fig. 5) with angular postero-ventral corner, anterior and ventral margins convex; postero-ventral corners of plates I-III with one robust seta each, and with one, two and two simple setae posteriorly, respectively. Epimeral plates II-III with three and two robust setae along of ventral margins, respectively.

Pleonites I-III each with one to two simple setae along dorsal surface. Peduncle of pleopod I with two simple setae and two-hooked retinacles along of inner margin (Fig. 5); peduncle of pleopod II with two-hooked retinacles at distal part of inner margin; peduncle of pleopod III with two-hooked retinacles and with one simple seta at distal part of inner margin; rami of pleopods I-III each with 10 to 14 articles (Fig. 5).

Laterally, urosomites I-III with one robust seta, two robust setae and one simple seta and without setae, respectively. Peduncle of uropod I with five and two large robust setae along dorso-lateral and dorso-medial margins, respectively. Outer ramus as long as inner ramus; inner ramus with three groups of robust setae laterally and five robust setae distally; outer ramus with four groups of seven robust setae laterally and five robust setae distally (Fig. 5). Inner ramus in uropod II longer than outer, both rami with lateral and distal long robust setae (Fig. 5). Uropod III long, almost 0.5 of body length. Peduncle of uropod III with five robust setae. Outer ramus biarticulated, distal article 0.19 proximal article. Proximal article of outer ramus bearing seven and eight groups of robust setae along inner and outer margins (Fig. 5); distal article with simple setae laterally and four simple setae distally. Inner ramus short, with two robust and one simple distal setae. Telson longer than broad, lobes slightly narrowing; each lobe with three robust setae distally and with two plumose setae laterally (Fig. 5).

Etymology - The species is named in honour of Professor Alireza Sari, University of Tehran, Iran, to acknowledge his many years of contribution to the zoology of Iran, especially his work on crustaceans. 


\section{Phylogenetic relationships and molecular divergence}

We analysed 53 Niphargus species (63 individuals) based on 810 base pairs of the first fragment of the $28 \mathrm{~S}$ ribosomal DNA gene. Two phylogenetic analyses (Bayesian inference and maximum likelihood) yielded similar topologies. The topology resulting from Bayesian inference analysis is presented in Figure 6. The newly described N. sarii sp. n. is nested within the main Iranian clade plus the specimen from Lebanon (which is juvenile and its identity could not be determined). This species shares an ancestor with $N$. hosseiniei, $N$. khayyami and N. sohrevardensis (Fig. 6). Pairwise uncorrected Kimura 2-parameter genetic distances and patristic distances on a $28 \mathrm{~s}$ maximum likelihood tree between all Iranian species and the Lebanon sample are presented in Table 2. The K2P genetic distances between the $N$. sarii and other species ranged between $0.60 \%$ and $10.80 \%$, and the patristic distance is between $0.90 \%$ and $28.60 \%$. The new species is genetically most similar to $N$. sohrevardensis $(0.60 \%$ $\mathrm{K} 2 \mathrm{P}$ and $0.90 \%$ patristic divergence in the studied $28 \mathrm{rDNA}$ gene fragment) and the most divergent species from $N$. daniali, $(10.08 \% \mathrm{~K} 2 \mathrm{P}$ and $28.60 \%$ patristic divergence). Minimum interspecific distance was observed between two previously known species $N$. persicus and $N$. darvish $i$ with the least divergence of $0.30 \%$ in both $\mathrm{K} 2 \mathrm{P}$ and patristic divergence.

\section{DISCUSSION}

The study of collected populations from Ilam Province proposes a new species of Niphargus genus, on the basis of morphological characters and the DNA sequences of $28 \mathrm{~S}$ ribosomal DNA (rDNA) gene. The DNA sequences confirmed the relative taxonomic position of $N$. sarii sp. n. with $N$. sohrevardensis, N. hosseiniei and N. khayyami. The Bayesian and ML analyses indicate that this species is phylogenetically distinct of other relative species. All Iranian species (except $N$. daniali plus a sample from Lebanon) constitute a large, strongly supported monophyletic clade that is separated from European taxa. Two individuals of the newly described species constitute a strongly supported monophylum that differs from $N$. sohrevardensis in $0.60 \%$ and $0.90 \%$ of base pairs based on Kimura two parameter and patristic distances, respectively. According to Hou and Li (2010) and Esmaeili-RineH et al. (2015a, 2016), this is within the same range of divergence for $28 \mathrm{~S}$ gene as in well-defined Gammarus and Niphargus species.

Fig. 6. Bayesian consensus tree of 53 Niphargus species (52 taxa from Esmaeili-Rineh et al. 2015a, 2017a), based on the $28 S$ ribosomal DNA sequences. Species are identified and named according to the valid taxonomic descriptions. Numbers above line indicate the posterior probabilities of the nodes in the Bayesian inference analysis. Numbers below line are the bootstrap values of the nodes in the Maximum likelihood analysis 


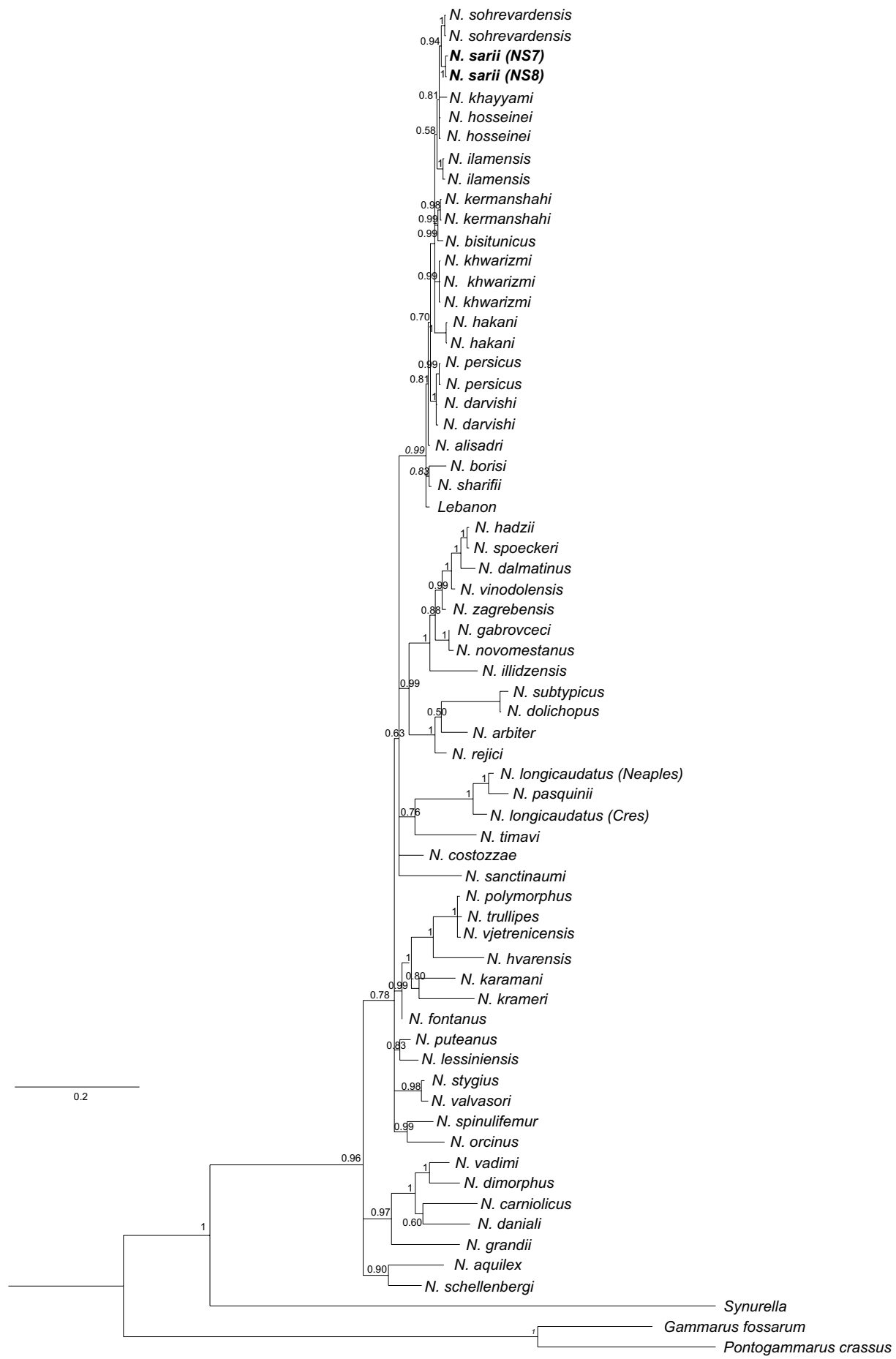




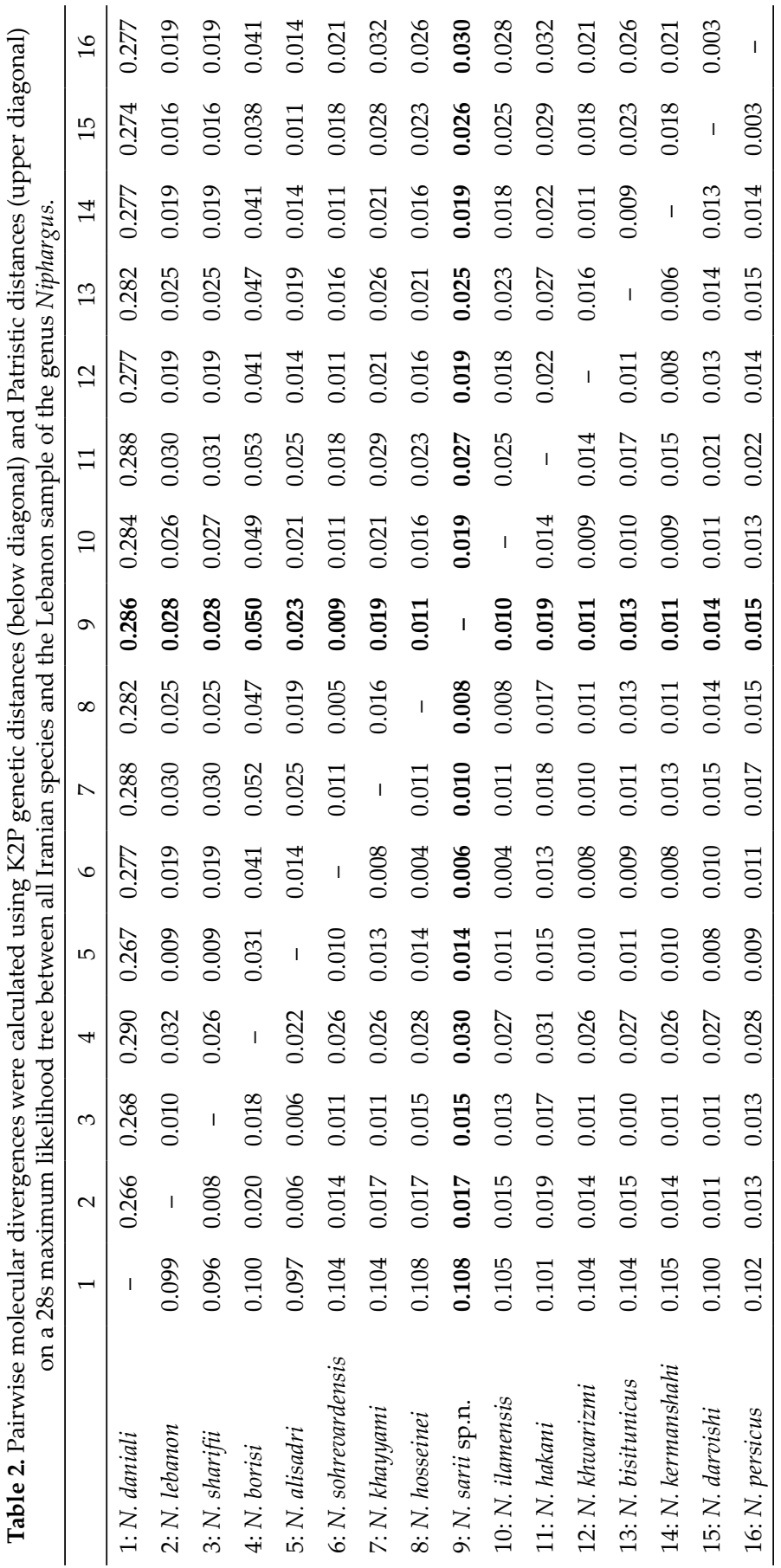




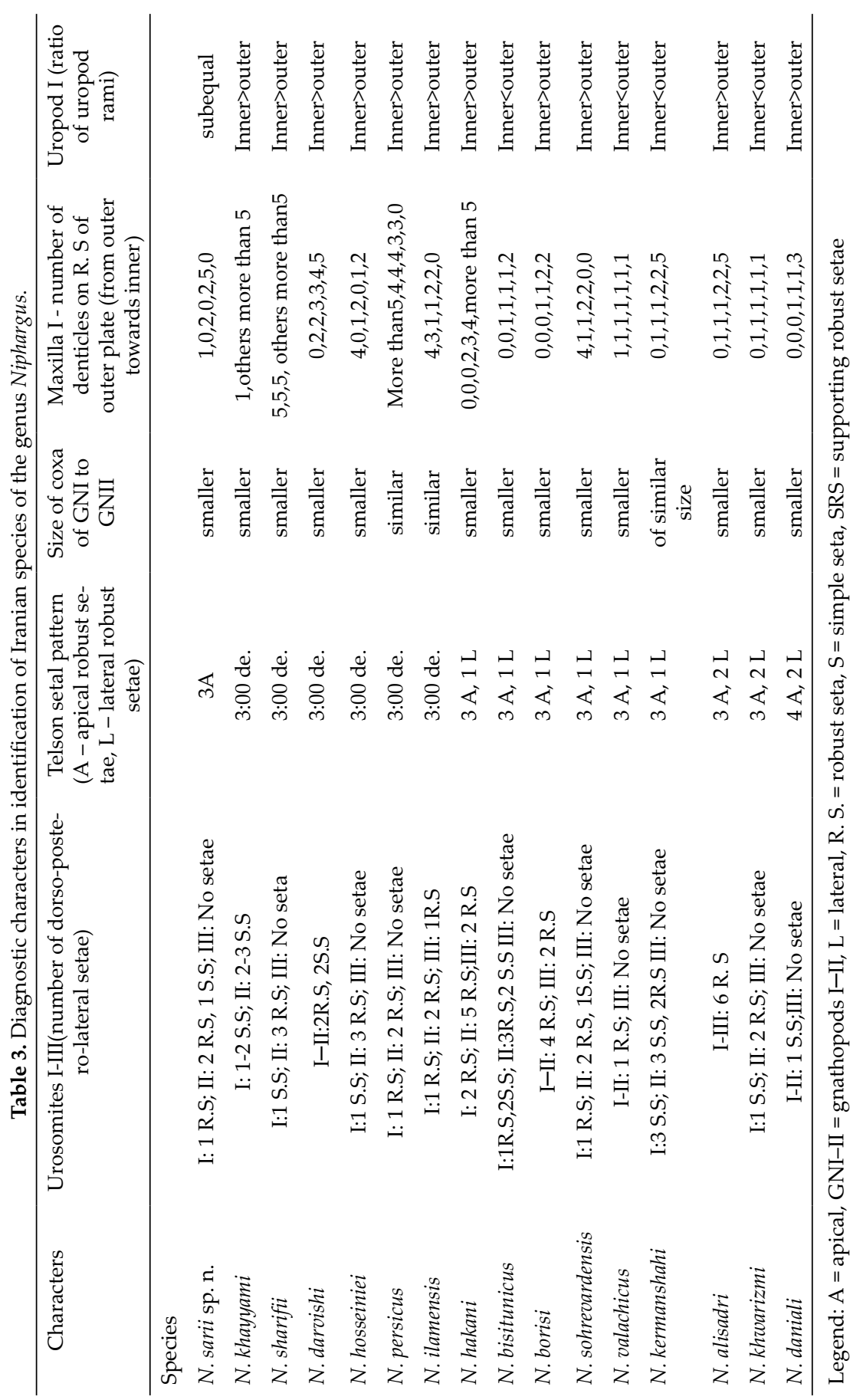




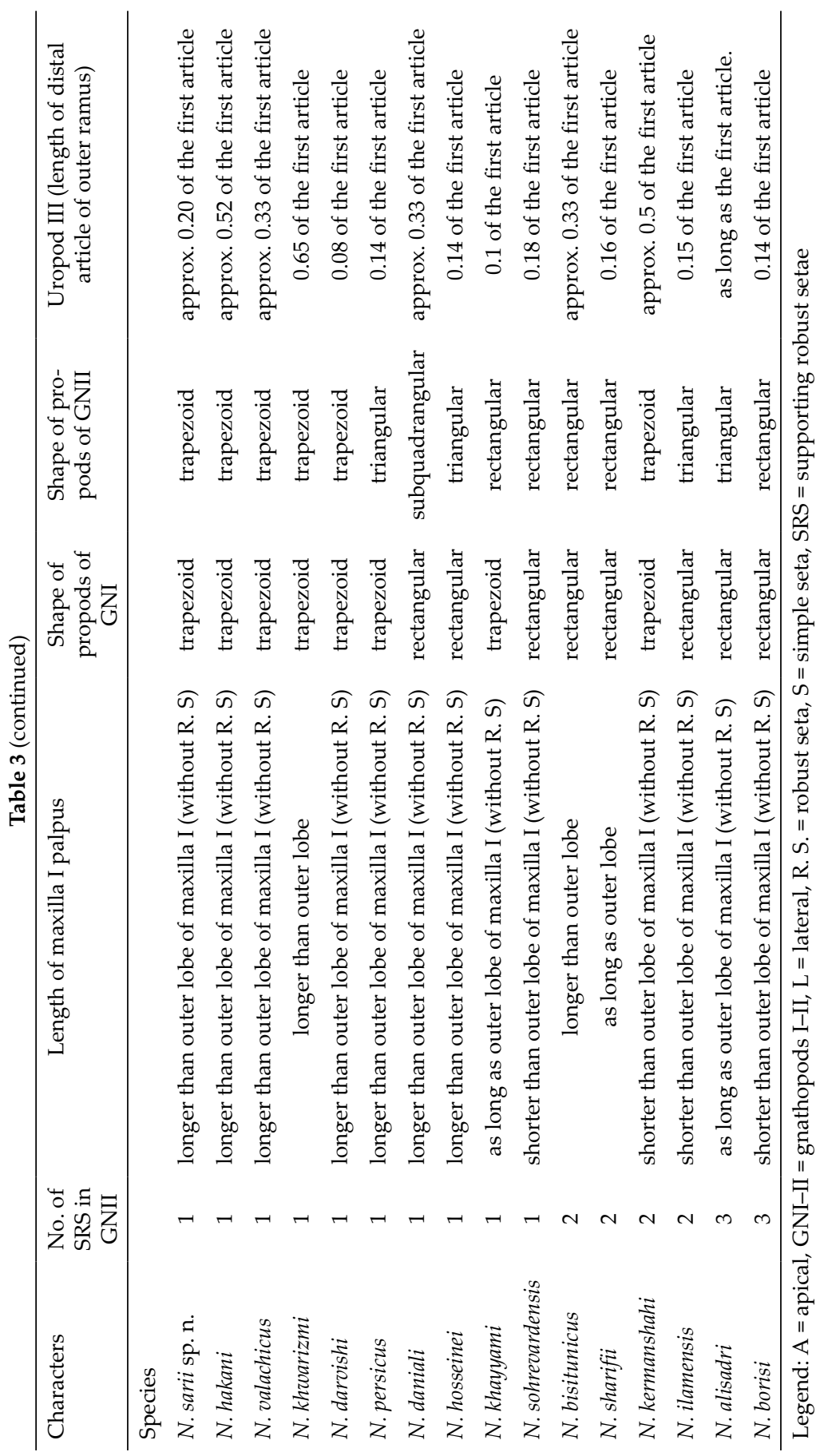


$N$. sarii sp. n. is geographically far from its sister species N. sohrevardensis. This is a surprise, as Niphargus species are in general poorly vagile, and closely related species often share the same geographic region (FIšER et al. 2008, Trontelj et al. 2009, Meleg et al. 2013). The distance between the two species is $323.5 \mathrm{~km}$. Moreover, the distances between $N$. sarii with $N$. hosseiniei and N. khayyami are 127.3 and $121.4 \mathrm{~km}$, respectively.

The species is also morphologically distinct from other Iranian species. A shortened comparison of diagnostic traits for the Iranian species is presented in Table 3. Both species share several morphological traits in the ratio of second to first article of the outer ramus of uropod III, the number of supporting robust setae in the palmar corner of gnathopods I-II and the number of robust and simple setae in dorso-lateral urosomites I-III surface. However, this species differs from N. sohrevardensis in the shape of propodus of gnathopods I-II, by the absence of lateral robust setae in telson, by the ratio of rami length in uropod I and by the outer plate longer than the palpus in maxilla I (EsMAEILIRineH et al. 2017b). Thus, the evidence from both morphological and molecular studies supports N. sarii sp. n. as new species (Table 3).

The new species resembles $N$. hosseiniei in distal robust setae in telson, the ratio of maxillar palpus to outer plate length in maxilla I and in the shape of the postero-ventral angle of epimeral plates. The two species differ from each other in the ornamentation of the lateral projections of the robust setae in outer plate of maxilla I, the number of robust and simple setae in dorso-lateral urosomites I-III surface and the ratio of the inner to outer ramus of uropod I and the shape of propodus in gnathopods I-II. N. hosseiniei is recognizable by rectangular and triangular propodi in gnathopods I-II, respectively, whereas N. sarii sp. n. bear trapezoidal shape propodi in both gnathopods. Also, $N$. hosseiniei individuals bear double palmar robust setae that was not observe in other Iranian species (Esmaeili-RineH et al. 2017b). Niphargus khayyami differs from N. sarii sp. n. by the ratio of inner to the outer ramus of uropod I, by the ratio of palpus to outer plate length in maxilla I and ornamentation of lateral projections of robust setae in outer plate of maxilla I (HeкMATARA et al. 2013).

An important diagnostic trait of $N$. sarii sp. n. is the equal ratio of the length of rami in uropod I. This character was not observed in other Iranian species (Karaman 1998, Hekmatara et al. 2013, Esmaeili-Rineh et al. 2015b, 2016a). This character seen only in N. nadarini favitor in the Middle East (Karaman 2012), but, two taxa differ in the ratio of palpus to outer plate length in maxilla I, the number of robust setae at the base of nail in pereopods IV-VII and the number of robust setae in outer surface of palmar corners in gnathopods I-II.

Finally, we describe the new taxon and increase the Iranian niphargid fauna to 17 species. Most of the species are endemic to Iran. Endemic species are an important part of the natural heritage of the country. Therefore, it is necessary to identify the biodiversity of this area before habitat destruction. 
Acknowledgements - This project was financially supported by Razi University as a part of the MSc thesis of second author. We are especially grateful to Prof. Gábor Bakonyi, Editor-in-Chief of Journal and two anonymous reviewers significantly improved an early version of the manuscript.

\section{REFERENCES}

Afroosheh, M., Akmali, V., Esmaeili-Rineh, S. \& Sharifi, M. (2016): On the distribution, abundance and conservation status of the endangered yellow spotted mountain newt Neurergus microspilotus (Caudata: Salamandridae) in western Iran. - Herpetological Conservation and Biology 11(1): 52-60.

Akmali, V., Farazmand, A., Darvish, J. \& Sharifi, M. (2011): Phylogeography and taxonomic status of the greater mouse-tailed bat Rhinopoma microphyllum (Chiroptera: Rhinopomatidae) in Iran. - Acta Chiropterologica 13: 279-290. https://doi. org/10.3161/150811011X624767

Akmali, V., Mehdizadeh, R., Chaghamirza, K., Moradi, M. \& Sharifi, M. (2015): Taxonomic evaluation of the bent-winged bat (Miniopterus) populations occurring in Iran inferred from mitochondrial cytochrome-b sequences. - Mammalia 79(4): 449-455. https://doi.org/10.1515/mammalia-2014-0002

Bousfield, E. L. (1977): A new look at the systematics of gammaridean amphipods of the world. - Crustaceana Supplement 4: 282-316.

Christman, M. C. (2005): Mapping subterranean biodiversity. Pp. 355-361. In: Culver, D. C. \& White, W. B. (eds): Encyclopedia of caves. - Elsevier/Academic Press, Amsterdam.

CoAd, B. W. \& Vhlenkin, B. Y. (2004): Co-occurrence and zoogeography of the freshwater fishes of Iran. - Zoology in the Middle East 31: 53-61. https://doi.org/10.1080/09397140 .2004 .10638022

Fathipour, F., Sharifi, M. \& Akmali, V. (2016): Distribution of cavernicolous bat fauna in Ilam Province, Western and Southwestern of the Iranian Plateau. - Iranian Journal of Animal Biosystematics 12 (1): 97-110. https://doi.org/10.22067/ijab.v12i1.46405

Esmaeili-Rineh, S. \& SARI, A. (2013): Two new species of Niphargus Schiödte, 1849. (Crustacea: Amphipoda: Niphargidae) from two caves in Iran. - Journal of Natural History 47: 2649-2669. https://doi.org/10.1080/00222933.2013.802041

Esmaeili-Rineh S., SARi, A., Delić, T., MošKrič, A. \& FišEr, C. (2015a): Molecular phylogeny of the subterranean genus Niphargus (Crustacea: Amphipoda) in the Middle East: A comparison with European niphargids. - Zoological Journal of Linnean Society 175: 812-826. https://doi.org/10.1111/zoj.12296

Esmaeili-Rineh, S., SARI, A., \& FišER, C. (2015b): Making future taxonomy of Niphargus (Crustacea: Amphipoda: Niphargidae) in the Middle East easier: DELTA database of Middle East species with description of four new species from Iran. - Zootaxa 4020: 401-430. https://doi.org/10.11646/zootaxa.4020.3.1

Esmaeili-Rineh, S., Heidari, F., Fišer, C. \& Akmali, V. (2016a): Description of new endemic species of the genus Niphargus Schiödte, 1849 (Amphipoda: Niphargidae) from a karst spring in Zagros Mountains in Iran. - Zootaxa 4126: 338-350. https://doi. org/10.11646/zootaxa.4126.3.2

Esmaeili-Rineh, S., Akmali, V., Fathipour, F., Heidari, N. \& Rastegar-Pouyani, N. (2016b): New distribution records of cave-dwelling gekkonid lizards (Sauria, Gekko- 
nidae and Phyllodactylidae) in the Zagros Mountains of Iran. - Subterranean Biology 18: 39-47. https://doi.org/10.3897/subtbiol.18.8185

Esmaeili-Rineh, S., Mirghaffari, S. A. \& Sharifi, M. (2017a): The description of a new species of Niphargus from Iran based on morphological and molecular data. - Subterranean Biology 22: 43-58. https://doi.org/10.3897/subtbiol.22.11286

Esmaeili-Rineh, S., SARI, A., FišEr, C. \& BARgrizaneh, Z. (2017b): Completion of molecular taxonomy: description of four amphipod species (Crustacea: Amphipoda: Niphargidae) from Iran and release of database for morphological taxonomy. - Zoologischer Anzeiger 271: 57-79. https://doi.org/10.1016/j.jcz.2017.04.009.

FIšER, C. (2012): Niphargus: a model system for evolution and ecology. Pp. 555-564. In: Culver, D. C. \& White, W. B. (eds): Encyclopedia of caves. - Academic Press, New York. https://doi.org/10.1016/B978-0-12-383832-2.00082-7

Fišer, C. \& Zagmajster, M. (2009): Cryptic species from cryptic space: the case of Niphargus fongi sp. (Amphipoda, Niphargidae). - Crustaceana 82: 593-614. https:// doi.org/10.1163/156854009X407704

Fourment, M. \& Gibs, M. J. (2006): Patristic: a program for calculating patristic distances and graphically comparing the components of genetic change. - BMC Evolutionary Biology 6:1. https://doi.org/10.1186/1471-2148-6-1

Guindon, S. \& GAscuel, O. (2003): A simple, fast, and accurate algorithm to estimate large phylogenies by maximum likelihood. - Systematic Biology 52: 696-704. https://doi. org/10.1080/10635150390235520

HaLl, T. A. (1999): BioEdit: a user-friendly biological sequence alignment editor and analysis program for Windows 95/98/NT. - Nucleic Acids Symposium Series 41: 95-98.

Hekmatara, M., ZaKšek, V., Heidari, M. B. \& Fišer, C. (2013): Two new species of Niphargus (Crustacea: Amphipoda) from Iran. - Journal of Natural History 47: 1421-1449. https:// doi.org/10.1080/00222933.2012.743616

Karaman, G. S. (1998): First discovery of the family Niphargidae (Gammaridea) in Iran (Contribution to the knowledge of the Amphipoda 243). - Glasnik Odjeljenja prirodnih Nauka - Crnogorska Akademija Nauka i Umjetnosti 12: 9-22.

Karaman, G. S. (2012): Further studies on genus Niphargus Schiödte, 1849 (fam. Niphargidae) from the near east (contribution to the knowledge of the Amphipoda 260). - Agriculture and Forestry 55: 49-74.

Khalaji-Pirbalouty, V. \& Sari, A. (2006): Description of Gammarus balutchi sp. nov. (Amphipoda: Gammaridae) from Iran, based on light and electron microscopy. - Zoologische Mededelingen Leiden 80: 91-100.

Kimura, M. (1980): A simple method for estimating evolutionary rate of base substitutions through comparative studies of nucleotide sequences. - Journal of Molecular Evolution 16: 111-120. https://doi.org/10.1007/BF01731581

LAtreille, P. A. (1816): Amphipoda. In: Nouveau Dictionaire d'histoire naturelle, appliquée aux Arts, à l'Agriculture, à l'Économie rurale et domestique, à la Médecine, etc. - Par une société de Naturalistes et d'Agriculteurs. 2nd edition. Volume 1. Deterville, Paris.

LefÉbure, T., Douady, C. J., Gouy, M. \& Gibert, J. (2006): Relationships between morphological taxonomy and molecular divergence within Crustacea: Proposal of a molecular threshold to help species delimitation. - Molecular Phylogenetics and Evolution 40: 435-447. https://doi.org/10.1016/j.ympev.2006.03.014

Lowry, J. K. \& Myers, A. A. (2013): A phylogeny and classification of the Senticaudata subord. nov. (Crustacea: Amphipoda). - Zootaxa 3610: 1-80. https://doi.org/10.11646/ zootaxa.3610.1.1 
Mamaghani-Shishvan, M., Esmaeili-Rineh, S. \& Fišer, C. (2017): An integrated morphological and molecular approach to a new species description of amphipods in the Niphargidae from two caves in west of Iran. - Zoological Studies 56: 33. https://doi. org/10.6620/ZS.2017.56-33

Meleg, I. N., ZaKšeK, V., Fišer, C., Kelemen, B. S. \& Moldovan, O. T. (2013): Can environment predict cryptic diversity? The case of Niphargus inhabiting Western Carpathian groundwater. - PLoS ONE 8: e76760. https://doi.org/10.1371/journal.pone.0076760

PosAdA, D. (2008): jModelTest: Phylogenetic model averaging. - Molecular Biology and Evolution 25: 1253-1256. https://doi.org/10.1093/molbev/msn083

RAeisi, E. (2004): Iran cave and karst. In: GunN, J. (ed.): Encyclopedia of cave and karst. Fitzroy Dearborn, New York.

Raeisi, E. \& Stevanovic, Z. (2010): Case study: Springs of the Zagros mountain range Iran and Iraq. In: Kresic, N. \& Stevanovic, Z. (eds): Groundwater hydrology of springs: Engineering, theory, management and sustainability. - Elsevier Inc. https://doi. org/10.1016/B978-1-85617-502-9.00025-6

Rambaut, A. \& Drummond, A. J. (2009): Tracer v1.5.0. Available at http://beast.community/ tracer

Ronquist, F. \& Huelsenbeck, J. P. (2003): MrBayes 3: Bayesian phylogenetic inference under mixed models. - Bioinformatics 19: 1572-1574. https://doi.org/10.1093/bioinformatics/btg180

Sargeran, P., Bakhtiyari, M., Abdoli, A., Coad, B.W., Sarvi, K., Rahmati, M. \& HajimoRADLOO, A. (2008): The endemic Iranian Cave-fish, Iranocypris typhlops: two taxa or two forms based on the mental disc? - Zoology in the Middle East 44: 67-74. https://doi. org/10.1080/09397140.2008.10638290

Sсніӧрте, J. G. (1849): Bidrag til den underjordiske fauna. - Det kong danske vidensk Selsk krifter Femte Raekke Naturv Mathem Afd Andet Bind. Copenhagen.

Shahabi, S., Akmali, V. \& Sharifi, M. (2017): Distribution and abundance of cave-dwelling bats in Fars province in south west of Iran. - Species 18: 91-116.

SKET, B. (1981): Distribution, ecological character and phylogenetic importance of Niphargus valachicus. - Bioloski Vestnik 29: 87-103.

Smith, A. (1953): Blind White Fish in Persia. - George Allen \& Unwin, London, 231 pp.

Tamura, K., Peterson, D., Peterson, N., Stecher, G., Nei, M. \& Kumar, S. (2011): MEGA5: Molecular evolutionary genetics analysis using maximum likelihood, evolutionary distance, and maximum parsimony methods. - Molecular Biology and Evolution 28: 2731-2739. https://doi.org/10.1093/molbev/msr121

Thompson, J. D., Higgins, D. G. \& Gibson, T. (1994): Clustal W: improving the sensitivity of progressive multiple sequence alignment through sequence weighting, position specific gap penalties and weight matrix choice. - Nucleic Acids Research 22: 4673-4680. https://doi.org/10.1093/nar/22.22.4673

Verovnik, R., Sket, B. \& TrontelJ, P. (2005): The colonization of Europe by the freshwater crustacean Asellus aquaticus (Crustacea: Isopoda) proceeded from ancient refugia and was directed by habitat connectivity. - Molecular Ecology 14: 4355-4369. https:// doi.org/10.1111/j.1365-294X.2005.02745.x

ZAKšek, V., SKet, B. \& Trontelj, P. (2007): Phylogeny of the cave shrimp Troglocaris: evidence of a young connection between Balkans and Caucasus. - Molecular Phylogenetics and Evolution 42: 223-235. https://doi.org/10.1016/j.ympev.2006.07.009

Received July 28, 2017, accepted November 10, 2017, published May 31, 2018 